Tersedia Online: http://journal.uny.ac.id/index.php/jpep

\title{
MODEL PENDIDIKAN KARAKTER BAGI ANAK MELALUI "SEKOLAH IBU” NONFORMAL DI PEDESAAN
}

\author{
Yoyon Suryono, Puji Yanti Fauriah \\ Universitas Negeri Yogyakarta, Universitas Negeri Yogyakarta \\ yoyonsuryono@yahoo.com,pujiyanti@uny.ac.id
}

\begin{abstract}
Abstrak
Tujuan penelitian ini adalah mengembangkan model pendidikan karakter bagi anak sejak dini melalui program terpadu "Sekolah Ibu" PAUD nonformal di pedesaan. Metode penelitian menggunakan penelitian dan pengembangan dilaksanakan di Kecamatan Pajangan Kabupaten Bantul terhadap $11 \mathrm{~KB}$ dan 11 SPS dengan responden orang tua sebanyak 60 orang. Hasil penelitian menunjukkan bahwa KB dan SPS yang diteliti dapat dikembangkan menjadi "Sekolah Ibu" dengan sasaran para orang tua yang putra-putrinya sedang mengikuti kegiatan pembelajaran. Materi pokok yang diberikan mencakup pendidikan karakter bagi anak, pola pengasuhan anak di rumah, dan model pembelajaran bagi anak usia dini. Hasil penelitian tersebut kemudian dikembangkan dalam satu model konseptual-teoritik pendidikan karakter bagi anak sejak dini melalui "Sekolah Ibu" PAUD nonformal di pedesaan dengan dilengkapi materi modul pembelajaran pendidikan karakter bagi anak sejak dini.
\end{abstract}

Kata kunci: pendidikan karakter, pendidikan anak usia dini, pendidikan nonformal, "Sekolab Ibu"

\section{A MODEL OF CHARACTER EDUCATION FOR CHILDREN THROUGH THE “MOTHER SCHOOL” NONFORMAL IN RURAL AREAS}

\author{
Yoyon Suryono, Puji Yanti Fauriah \\ Universitas Negeri Yogyakarta, Universitas Negeri Yogyakarta \\ yoyonsuryono@yahoo.com, pujiyanti@uny.ac.id
}

\begin{abstract}
This study attempted to develop a model of character education for early childhood through an integrated program "Mother School" in non-formal PAUD at a countryside. This study uses the approach of research and development implemented in the district of Bantul Pajangan to $11 \mathrm{~KB}$ and 11 of the SPS with parent respondents of 60 people. The results show that KB and SPS which were studied can be developed into a "Mother School" by targeting the parents whose children were participating in learning activities. The subject matters given include character education for children, parenting at home, and a model for early childhood learning. Then, the result of the research was developed in a conceptual-theoretical model of character education for early childhood through "Mother School" non-formal PAUD in the countryside including learning modules of character education materials for early childhood.
\end{abstract}

Keywords: character education, early childhood education, non-formal education, "School Mother" 



\section{Pendahuluan}

Anak sejak usia dini perlu ditanamkan karakter positif untuk bekal kehidupannya kelak di masa depan, salah satunya adalah melalui pendidikan karakter bagi anak sejak dini dalam wadah "Sekolah Ibu" PAUD nonformal di pedesaan. Sejauh ini pendidikan karakter telah diberikan pada anak-anak secara langsung, baik di rumah oleh orang tua maupun di lembaga PAUD formal dan nonformal seperti Taman Kanak-kanak (TK), Kelompok Bermain (KB), Taman Penitipan Anak (TPA) maupun Satuan Pendidikan Sejenis (SPS) oleh pendidik, pendamping, dan pengasuh anak di pedesaan dan di perkotaan. Hal menarik dari pelaksanaan pendidikan karakter selama ini adalah berkurangnya peran ibu dalam mengkarakterkan anak di rumah antara lain karena: ibu bekerja, berkembangnya lembaga dan layanan PAUD, kurangnya keterpaduan pendidikan karakter anak di rumah dan di lembaga PAUD. Ketimpangan lain adalah antara PAUD di perkotaan dan di pedesaan. PAUD di perkotaan relatif lebih maju dibanding PAUD di pedesaan.

Pengembangan model pendidikan karakter bagi anak sejak dini melalui "Sekolah Ibu" PAUD nonformal di pedesaan dilaksanakan atas dasar pertimbangan hal-hal berikut: Lembaga PAUD nonformal yang sudah ada seperti KB, TPA, dan SPS agar lebih diberdayakan lagi dengan melibatkan para orang tua dalam melaksanakan pendidikan karakter bagi anak sejak dini melalui wadah "Sekolah Ibu". Hal ini merupakan pengembangan dari KB, TPA, dan SPS yang sudah ada yang dikhususkan bagi orang tua untuk bersama-sama lembaga PAUD formal dan nonformal melaksanakan pendidikan karakter bagi anak-anak sejak dini. Dalam konteks ini, anak merupakan sasaran utama dan orang tua merupakan sasaran perantara bagi terselenggaranya pendidikan karakter bagi anak sejak ini. Dalam posisi "perantara" inilah orang tua perlu dibekali dengan berbagai kemampuan untuk dapat melaksanakan pendidikan karakter bagi anak sejak dini di rumah sehingga terjalin keterpaduan pendidikan karakter yang dilaksanakan di rumah dengan di lembaga PAUD. Prinsip penting di sini adalah bahwa keluarga itu pendidik pertama dan utama yang harus secara lebih dini bertanggung jawab dalam mendidik karakter anak. Bersama keluarga kemudian lembaga PAUD melaksanakan pendidikan karakter bagi anak sejak dini secara bersama dan terpadu dalam satu kerja sama kemitraan yang sinergis.

Seiring dengan hal tersebut, melalui penelitian ini dikembangkan model pendidikan karakter bagi anak sejak dini melalui "Sekolah Ibu" PAUD nonformal di pedesaan. Mengapa pendidikan karakter bagi anak sejak dini perlu dilaksanakan melalui "Sekolah Ibu" PAUD nonformal di pedesaan? Pendidikan karakter bagi anak sejak dini perlu dilakukan oleh orang tua di rumah, selain di lembaga PAUD seperti yang selama ini telah dilaksanakan dengan berbagai keragaman pendekatan, metoda, teknik, dan bahkan media yang dipergunakan.

Sejauh yang dapat diketahui, pendidikan karakter bagi anak sejak dini yang dilaksanakan di rumah masih menemui beberapa kendala antara lain masih kurangnya pemahaman dan kemampuan orang tua dalam melaksanakan pendidikan karakter bagi anak sejak dini. Oleh karena itu, untuk meningkatkan keberhasilan pelaksanaan pendidikan karakter di rumah bagi anak sejak dini kepada orang tua, khususnya Ibu-ibu perlu diberikan pemahaman, penanaman sikap baru, dan kemampuan cara-cara melaksanakan pendidikan karakter bagi anak sejak dini melalui model yang dikembangkan dalam penelitian ini yaitu "Sekolah Ibu". Model "Sekolah Ibu" ini akan membekali orang tua melalui proses pembelajaran yang akan dilaksanakan suatu pemahaman, pengembangan sikap, dan kemampuan baru dalam mendidik karakter anak sejak diri di rumah bersama institusi PAUD nonformal lain di pedesaan yaitu melalui $\mathrm{KB}$, TPS, dan SPS secara bersama dan sinergis.

Dalam perspektif pendidikan nonformal, pengembangan program pendidikan nonformal dapat dikembangkan setidaknya dari model yang sudah ada dan mengembangkan model baru yang belum ada. Baik 
untuk mengembangkan model yang pertama maupun yang kedua terlebih dahulu harus dilaksanakan studi pendahuluan yang berupa need assessment atau identifikasi kebutuhan yang hasilnya akan menjadi masukan bagi perencanaan dan pengembangan program yang dimaksud. Perencanaan dan pengembangan program menjadi bagian dari manajemen program yang bergerak dalam suatu siklus bertahap mencakup asessment kebutuhan, perencanaan, pelaksanaan, monitoring, evaluasi, dan pengembangan program (Sudjana, 2005 dan Sumarno, 2011).

Di sisi materi, secara normatif-konseptual pendidikan karakter bagi anak setidaknya berisi: cita Tuhan dan segenap ciptaannya, kemandirian, disiplin, tanggung jawab, kejujuran amanah dan berkata bijak, hormat dan santun, dermawan, suka menolong dan kerja sama, percaya diri, kreatif, pantang menyerah, kepemimpinan dan keadilan, baik dan rendah hati, toleransi, kedamaian dan kesatuan. Prinsip pembelajaran karakter setidaknya ada beberapa prinsip diantaranya adalah memahamkan anak tentang karakter yang baik, implementasi karakter melibatkan seluruh komponen dalam lembaga, melibatkan partisipasi orang tua dan masyarakat, dan menumbuhkembangkan motivasi intrinsik pada anak. (Lickona 1992, p.152)

Pendidikan karakter bagi anak sejak dini merupakan bagian dari pendidikan anak usia dini sebagaimana didefinisikan oleh Wortham (2005), UNESCO, dan Ojala (Harkonen 1985, 1993). Pendidikan anak usia dini di dalamnya mengandung bagian penting pemahaman terhadap perkembangan anak yang memiliki variasi teori sebagaimana dikembangkan oleh Froebel dalam konsep kindergarten, Vygotsky dalam teori zone of proximal development (ZPD), Berk, Piaget, dan Ki Hajar Dewantoro.

Pendidikan karakter bagi anak sejak dini melalui "Sekolah Ibu" PAUD nonformal di pedesaan yang dikembangkan melalui penelitian ini memiliki dua sasaran yaitu ibu dan anak secara berjenjang. Artinya, ibunya didik terlebih dahulu kemudian ibu mendidik anaknya. Oleh karena itu, terjadi dua proses pembelajaran secara bersama. Pembelajaran pertama sasarannya ibu dan proses pembelajaran kedua sasarannya anak. Yang pertama berkait dengan teori pembelajaran orang dewasa dan teori pembelajaran pendidikan nonformal seperti teori Freire "problem posing", Knowles andragogy dan self-directive learning, Mezirov pembelajaran transformational, Rogers dengan self-actualization, Gagne dengan pemecahan masalah, action knowledge dari Barnes, dan experiential leaning theory dari Kolb (Suryono, 2012). Yang kedua berkait dengan teori perkembangan dan pembelajaran anak sebagaimana dikemukakan oleh para ahli perkembangan anak tersebut.

\section{Metode Penelitian}

Penelitian ini menggunakan pendekatan penelitian dan pengembangan (Borg, 1983) yang dilaksanakan dalam kurun waktu 3 (tiga) tahun. Pada tahun pertama studi eksplorasi dan kajian pustaka. Studi eksplorasi bertujuan untuk dapat memetakan permasalahan yang ada di lapangan serta sumber daya dukung berupa potensi lokal. Kajian pustaka dilakukan untuk menyusun model konseptual program terpadu "Sekolah Ibu" berdasarkan kajian teoritis dan empirik.

Untuk tahun kedua akan dilaksanakan validasi model program oleh para ahli dilanjutkan dengan melaksanakan uji coba model program secara terbatas. Pada tahun ketiga akan dilaksanakan uji coba model program pada skala yang lebih luas dan setelah itu dilakukan desiminasi atau penyebarluasan hasil pengembangan model.

Penelitian tahun pertama dilakukan di laboratorium luar-kampus Jurusan PLS FIP UNY yang berlokasi di Kecamatan Pajangan Kabupaten Bantul yang berada di wilayah pedesaan dengan mengambil sampel satuan PNF (KB dan SPS masing-masing 11 lembaga) dan orang tua warga belajar PAUD nonformal sebanyak 60 orang.

Pengumpulan data dilaksanakan dengan metoda observasi partisipatif, wawancara, dan dialog. Data yang diperoleh dalam penelitian ini berupa data kuantitatif dan data kualitatif. Berhubung dengan itu maka 
analisis data dilakukan dengan dua cara yaitu analisis kuantitatif dan kualitatif. Data kuantitatif dianalisis secara deskriptif menggunakan statistik deskritif dan hasilnya disajikan dalam bentuk tabel, grafik, atau diagram. Sementara itu data kualitatif dianalisis dengan menggunakan cara-cara analisis kualitatif .

\section{Hasil Penelitian}

Identitas Lembaga dan Responden

Penelitian ini dilaksanakan di $11 \mathrm{~KB}$ dan 11 SPS yang ada di Kecamatan Pajangan Kabupaten Bantul sebagai institusi PAUD nonformal di pedesaan. Responden dalam penelitian ini berjumlah 51 orang hadir yang merupakan orang tua dari anakanak yang mengikuti kegiatan KB dan SPS dari 60 orang yang diundang. Sebagian besar responden adalah perempuan (45\%), berpendidikan SD sekitar 9\%, SMP 21\%, SMA $45 \%$, sisanya sekitar $22 \%$ berpendidik- an diploma dan sarjana. Responden laki-laki sekitar 32\%, berpendidikan SD 15\%, SMP $17 \%$, SMA $51 \%$, dan sisanya perguruan tinggi 16\%. Dilihat dari pendidikan, sebaran latar belakang pendidikan responden lakilaki mendekati sama dengan tingkat pendidikan responden perempuan.

Dilihat dari tingkat pendapatan responden laki-laki dan perempuan sebarannya hampir sama yaitu sebagian besar berpenghasilan di bawah satu juta rupiah per bulan, terdapat sekitar $66 \%$ bagi laki-laki dan $48 \%$ responden perempuan. Pada kelompok responden laki-laki terdapat sekitar 19\% berpenghasilan di atas satu juta tetapi di bawah lima juta; untuk kelompok responden perempuan sisanya tidak memiliki penghasilan atau mengikuti suami.

\section{Keterlaksanaan Standar PAUD}

Hasil penelitian tingkat pencapaian pelaksanaan standar PAUD pada dua lembaga itu disajikan pada Gambar 1.

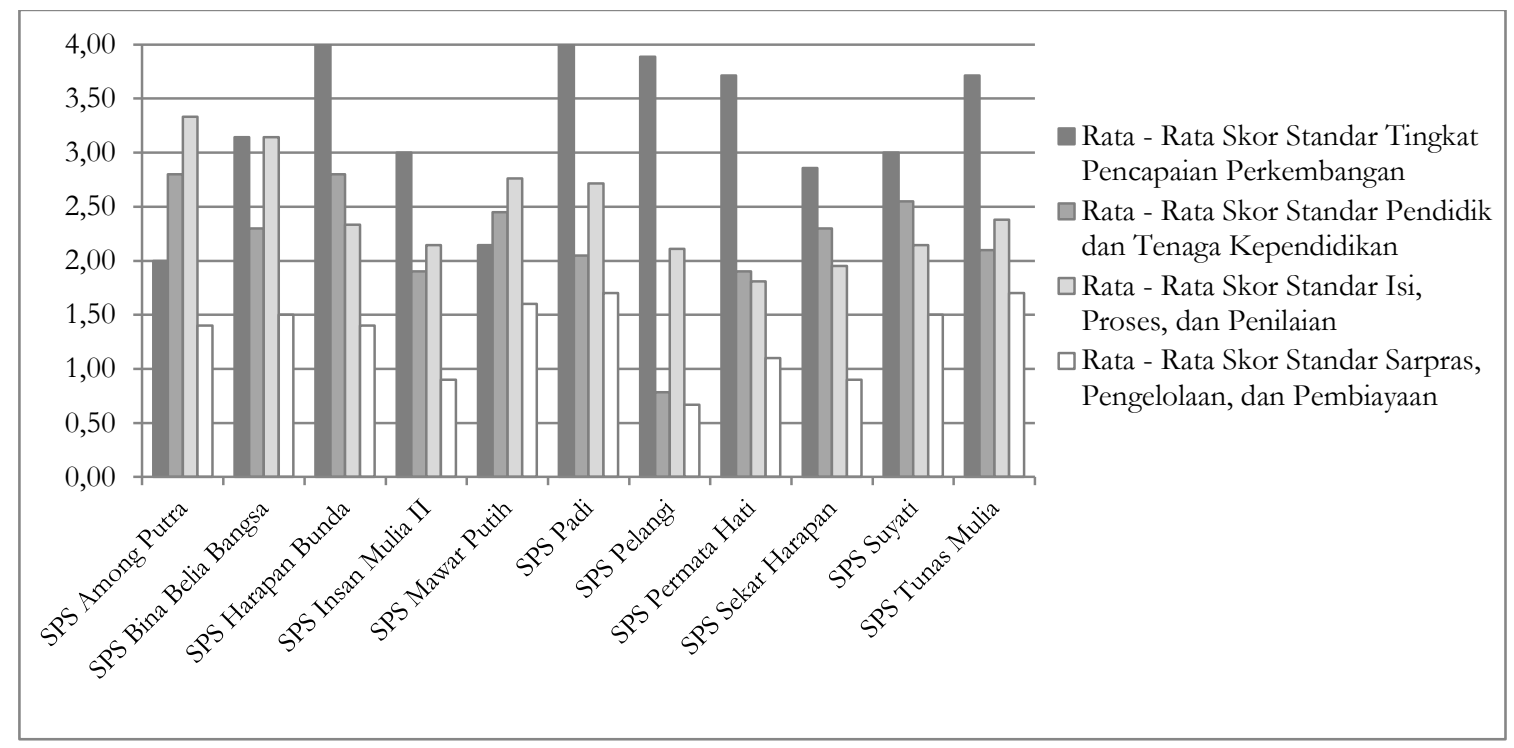

Gambar 1. Tingkat Pencapaian Standar PAUD pada SPS

Indikiator capaian perkembangan anak terdiri dari aspek capaian perkembangan sosial, emosional, moral, kognitif dan psikomotorik. Indikator Pendidik dan tenaga kependidikan terdiri dari tingkat pendidikan, pengalaman bekerja, pelatihan yang diikuti dan kegiatan penunjang lainnya. Dalam standar isi, proses dan penilaian yang men- jadi indikator penilaian adalah bagaimana pendidik melakukan proses pembelajaran dimulai dari aktivitas pembukaan, inti dan penutupan. Dan indikator sarana prasarana tinggi rendahnya capaian mutu dilihat dari ketersediaan pelbagai penunjang sarana pembelajaran seperti jumlah ruangan, kenyamanan ruangan, ketersediaan Alat Per- 
mainan Edukatif, APE luar, kamar mandi dan sarana prasarana minimal yang harusada dalam setiap layanan PAUD. Grafik menunjukkan tingkat pelaksanaan standar PAUD yang beragam baik pada standar tingkat pencapaian perkembangan, pendidik dan tenaga kependidikan, isi, proses, dan penilaian maupun standar sarpras, pengelolaan dan pembiayaan. Kesan umum dari data itu ialah adanya kecenderungan bahwa tingginya tingkat pencapaian perkembangan anak tidak dengan sendirinya didukung oleh tingkat pencapaian standar yang tinggi pada standar-standar lainnya bahkan dapat terjadi sebaliknya, artinya tingkat pencapaian perkembangan anak tinggi atau rendah tidak dengan sendirinya tingkat pencapaian standar yang lain juga tinggi atau rendah. Berikut beberapa kecenderungan yang terjadi di lapangan. Pertama, pada umumnya pencapaian tingkat perkembangan anak berada di posisi sedang dan tinggi, tetapi pencapaian tingkat standar pendidik dan tenaga kependidikan rendah, pencapaian tingkat standar isi, proses, dan penilaian rendah, dan pencapaian tingkat standar sarpras, pengelolaan dan pembiayaan rendah. Kedua, pencapaian tingkat perkembangan anak sedang dan tinggi, tingkat pencapaian standar pendidik adan tenaga kependidikan, rendah, tetapi tingkat pencapaian standar isi, proses, dan penilaian tinggi, diikuti oleh tingkat pencapaian standar sarpras, pengelolaan dan pembiayaan rendah. Ketiga, pola umum yang terjadi adalah pencapaian tingkat perkembangan anak sedang dan tinggi; pencapaian tingkat standar pendidik dan tenaga kependidikan rendah; pencapaian tingkat standar isi, proses, dan penilaian rendah; dan juga pencapaian tingkat perkembangan standar sarpras, pengelolaan dan pembiayaan rendah. Keempat, terdapat dua SPS yaitu SPS Among Putro dan SPS Mawar Putih yang menunjukkan adak berbeda dengan pola umum yaitu pada dua SPS ini tingkat pencapaian perkembangan anak rendah, tetapi tingkat pencapaian standar pendidik dan tenaga kependidikan serta standar isi, proses, dan penilaian tinggi, kecuali pada pencapaian tingkat standar sarpras, pengelolaan dan pembiayaan. Kelima, tingkat pencapaian standar pengelolaan dan pembiayaan seluruh SPS menunjukkan tingkat pencapaian yang rendah, tidak ada satupun yang berada dalam posisi sedang apalagi tinggi. Hal ini menunjukkan kemungkinan masalahan utama yang dihadapi adalah pada aspek sarpras, pengelolaan dan pembiayaan.

Data dalam Gambar 2 menunjukkan bahwa pada umumnya standar tingkat pencapaian perkembangan anak berada di Kelompok Bermain (KB) dalam posisi tinggi kecuali.

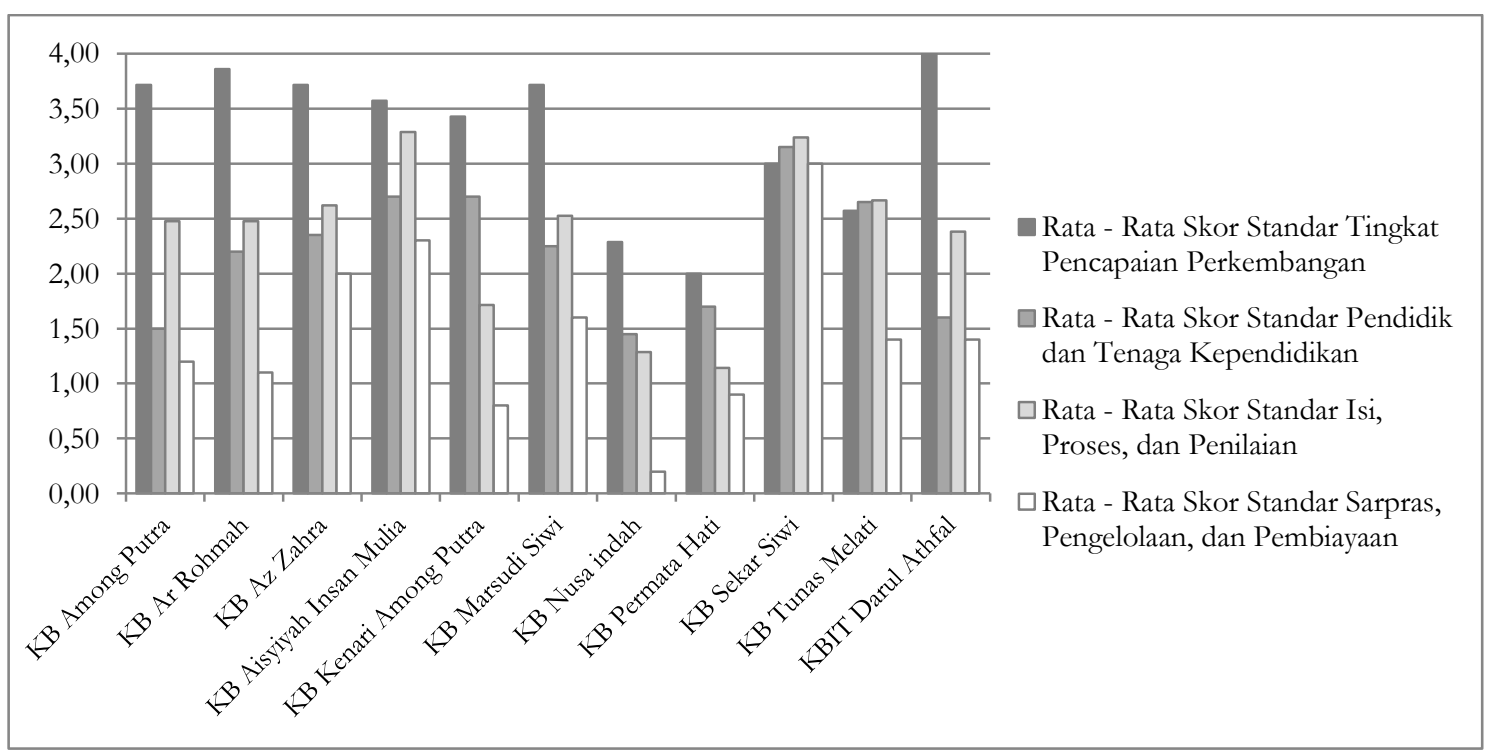

Gambar 2. Tingkat pencapaian Standar PAUD pada Kelompok Bermain (KB) 
Berbeda dengan itu, tingkat pencapaian standar pendidik dan tenaga kependidikan cenderung semuanya rendah. Tingkat pencapaian standar isi, proses, dan penilaian berkecenderungan sama meskipun sedikit variatif yaitu lebih banyak menunjuk pada posisi rendah. Sementara itu, tingkat pencapaian standar sarana dan prasarana, pengelolaan, dan pembiyaan seluruhnya berada dalam posisi rendah.

Rentang capaian mutu berada pada skala 1-4. Pola umum yang dapat diketahui dari data tersebut adalah: tingkat pencapaian perkembangan anak pada umumnya sedang dengan rerata skor sekitar 2,5; tingkat pencapaian standar pendidik dan tenaga kependidikan merata berada pada posisi sedang bergerak pada skor antara 1,5 sampai 3; tingkat pencapaian standar isi, proses, dan penilaian juga menunjukkan kondisi relatif sama berada pada posisi sedang bergerak pada skor sekitar 1,5 sampai 2,5; tingkat pencapaian standar sarana prasarana, pengelolaan, dan pembiayaan menunjukkan kondisi sama berada pada posisi rendah pada rentang skor 0,5 sampai 3 .

Kesimpulan umum yang dapat dikemukakan mengenai ketercapaian tingkat pemenuhan standar PAUD ini adalah tingkat pencapaian perkembangan anak pada umumnya lebih baik dibanding dengan tingkat pencapaian standar pendidik dan tenaga kependidikan, standar isi, proses, dan penilaian, serta standar sarana prasarana, pengelolaan, dan pembiayaan.

Pola Pengasuhan Anak dan Usulan "Sekolah Ibu"

Hasil penelitian berikut yang disajikan pada Gambar 3 akan menjelaskan kondisi pola pengasuhan anak oleh orang tua yang menjadi responden penelitian ini. Gambar 3 menunjukkan besaran persentase (y) atas 26 butir perilaku orang tua (garis $\mathrm{x}$ ) terhadap anak dalam masa pengasuhan anak yang muncul dalam beberapa pola asuh yang pernah atau sering diterapkan orang tua di Kecamatan Pajangan antara lain butir nomor 2 mendampingi kegiatan anak (68\%), mengajarkan kata maaf, butir nomor $11(77 \%)$, butir nomor 21 membantu menyiapkan se- mua keperluan anak (65\%) dan butir nomor 22 menyuapi anak ketika makan (61\%). Berdasarkan data tersebut, yang paling menonjol dan paling banyak dilakukan oleh sebagian besar orang tua terhadap anaknya di Kecamatan Pajangan adalah mengajarkan kata maaf dengan persentase $77 \%$ (butir nomor 11).

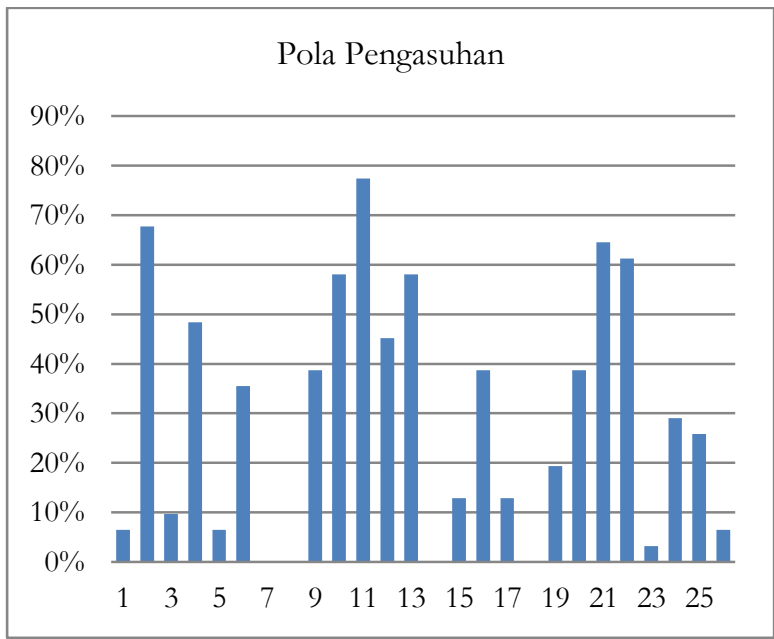

Gambar 3. Pola Pengasuhan Anak

Data itu menunjukkan bahwa hal terbanyak atau sering dilakukan oleh orang tua terhadap anak cenderung mengarah pada pola asuh otoriter. Pola asuh otoriter yang diterapkan tersebut tidak sepenuhnya keras pada anak, namun seiring dengan perkembangan dan bertambahnya usia anak, pola tersebut jika tetap diterapkan akan membuat anak tidak mandiri. Pada dasarnya mengajarkan kata maaf tidak selalu menunjukkan pola asuh otoriter, namun anak meminta maaf dengan kesadaran sendiri akan lebih baik dibandingkan meminta maaf karena disuruh. Membantu menyiapkan semua keperluan anak dan menyuapi anak jika dilakukan terus-menerus semakin membuat anak tidak bebas menentukan pilihannya sendiri. Anak cenderung menjadi manja dan tidak paham dengan kebutuhan sendiri. Orang tua yang lebih banyak mendampingi kegiatan anak sangat bagus untuk membantu anak lebih memahami sesuatu yang dilakukan anak. Anak punya kesempatan untuk bertanya kepada orang tua jika mengalami kesulitan, namun orang tua sebaiknya tidak berperan seperti "satpam" dan memberi ke-

Model Pendidikan Karakter bagi Anak Sejak Dini ... - 235

Yoyon Suryono, Puji Yanti Fauziah 
leluasaan pada anak. Dengan demikian anak tetap merasa nyaman tetapi tidak merasa takut diawasi orang tua.

Data selanjutnya yang menggambarkan pola asuh orang tua di Kecamatan Pajangan Bantul adalah butir nomor 10 meminta anak untuk membereskan setiap permainan (58\%), butir nomor 13 mengajarkan kata permisi (58\%), butir nomor 4 menaikkan suara bila anak melakukan kesalahan (48\%), butir nomor 12 mengajarkan kata minta tolong (45\%), butir nomor 9 membiarkan anak bereksplorasi (39\%), butir nomor 17 mendidik anak dengan keras untuk kebaikannya (39\%), butir nomor 20 mengontrol semua aktivitas anak (39\%), dan butir nomor 6 mendukung minat atau hobi anak yang berbeda dengan anak lain (35\%).

Pola asuh pada butir 13,12,9 dan 6 merupakan kelompok orang tua yang diterapkan oleh $39 \%$ orang tua terhadap anak di Kecamatan Pajangan mengarah pada pola asuh cenderung demokratis. Pada kegiatan meminta anak untuk membereskan setiap permainan, jika dilakukan orang tua diawal anak mengenal permainan sangat bagus untuk memberikan pengertian pada anak tentang tanggung jawab. Mengajarkan anak untuk mengucapkan kata permisi, mengucapkan kata minta tolong dan membiarkan anak bereksplorasi merupakan salah satu ciri pola asuh demokratis. Akan tetapi, orang tua perlu memperhatikan frekuensi perintah tersebut, agar anak mampu melakukan sendiri karena menyadari kegunaan hal tersebut tanpa sepengetahuan orang tua. Hal lain yang dilakukan sebagain kecil orang tua di Kecamatan Pajangan adalah menaikkan suara bila anak melakukan kesalahan dan mendidik anak dengan keras untuk kebaikannya. Pola asuh yang diterapkan tersebut jika dilakukan sesekali saja memberikan dampak positif terhadap perkembangan psikologis anak. Anak akan memahami maksud orang tersebut adalah bersikap tegas namun tidak dinilai kejam. Pada anak tertentu yang mendapat perlakukan keras secara terus menerus dapat mengakibatkan anak tidak berempati terhadap orang lain dan menerapkan perilaku seperti yang dilakukan orang tuanya jika bergaul dengan temannya. Sebaiknya orang tua perlu memprioritaskan kapan saatnya bicara keras dan setelah berbicara keras perlu memberikan pemahaman pada anak agar anak tidak salah persepsi dengan maksud orang tuanya.

Data selanjutnya jenis perilaku orang tua dengan persentase kurang dari (di bawah) $30 \%$ adalah butir nomor 1 menerapkan aturan dengan konsisten, butir nomor 3 mendongeng untuk anak, butir nomor 5 memukul/mencubit (member hukuman) anak agar disiplin, butir nomor 15 membiarkan anak menyelesaikan masalahnya sendiri, butir nomor 17 mendidik anak dengan keras untuk kebaikan dirinya, butir nomor 19 marah jika anak "ngeyel", butir nomor 23 memberikan apapun yang diminta anak, dan butir nomor 26 membiarkan anak menonton TV lebih dari 3 jam sehari.

Permasalahan yang tersirat dari data tersebut adalah: (1) Pada umumnya orang tua (dalam hal ini 30\%) selalu memberikan apa yang diinginkan anak sebagai bentuk ekspresi rasa kasih sayang orang tua, tetapi dalam kondisi tertentu sangat penting di belajarkan pada anak kondisi yang tidak selamanya orang tua dapat memenuhi keinginginan dan permintaan anak, anak dibelajarkan dan dipahamkan bahwa ketika keinginan anak tidak dipenuhi bukan berarti orang tua tidak menyayangi anak. (2) Orang tua yang menginginkan kebaikan untuk anaknya sangat baik, tetapi yang harus digarisbawahi adalah bentuk "kebaikan" seperti apa yang harus diberikan kepada anak, menonton TV lebih dari 3 jam dalam persepsi orang tua adalah baik untuk anak, orang tua tidak mengetahui dan menyadari dampak negatif dari menonton TV untuk anak khususnya untuk anak usia dini. Sehingga pemahaman orang tua yang berkaitan dengan "kebaikan" dapat diperkuat kembali melalui skeolah ibu. (3) Hal lain yang perlu diperhatikan adalah inkonsistensi orang tua dalam menghadapi perilaku anak, dalam pernyataan dikatakan bahwa orang tua bertindak keras tetapi disisi lain orang tua selalu mengikuti keinginan anak. Konsistensi sikap orang tua sangat diperlukan 
oleh anak untuk meyakinkan bahwa apa yang dilakukan adalah benar. Jika orang tua tidak konsisten akan menyebabkan anak bingung, mana yang boleh dan tidak boleh dan pada akhirnya orang tua tidak mendapat kepercayaan dari anak.

Aspek lain yang diungkap dalam penelitian ini adalah pendapat orang tua terhadap materi-materi apa yang perlu disampaikan kepada anak untuk mengembangkan karakter anak sejak dini dalam program terpadu "Sekolah Ibu". Hasil penelitian yang mengungkap hal tersebut disajikan pada Gambar 4 yang berisi tentang (1) tumbuh kembang anak, (2) metoda pendidikan anak, (3) kesehatan anak, (4) pola asuh sehat di rumah, (5) mendidik kemandirian anak, (6) latihan ke "toilet", dan (7) pilihan lain sesuai pendapat orang tua.

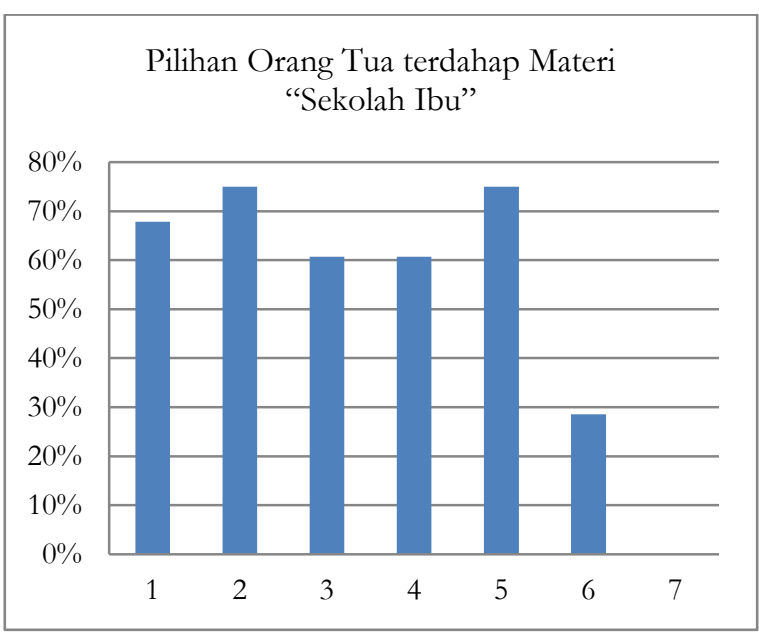

Gambar 4. Pilihan Orang Tua terdahap Materi "Sekolah Ibu"

Data yang diperoleh disajikan pada Gambar 4, sumbu vertikal menunjuk persen, dan sumbu horizontal menunjuk pilihan materi, menginformasikan bahwa kebutuhan orang tua yang paling menonjol dalam pendidikan anak adalah butir 2 mendapatkan tambahan wawasan mengenai metode pendidikan anak $(75 \%)$ dan butir nomor 5 mendidik kemandirian anak $(75 \%)$. Selanjutnya butir nomor 1 kebutuhan terhadap materi tumbuh kembang anak (68\%), materi butir nomor 3 tentang kesehatan anak $(61 \%)$ dan materi butir nomor 4 pola asuh sehat di rumah (61\%). Materi yang selanjutnya dengan persentase paling rendah adalah tentang toilet training, yaitu butir nomor 6 .

Berdasarkan data tersebut dapat diambil kesimpulan bahwa materi yang sangat dibutuhkan oleh sebagian besar orang tua di Kecamatan Pajangan Bantul adalah materi tentang metode pendidikan anak dan cara mendidik anak mandiri. Dengan demikianm, orang tua mengetahui dan memahami strategi mendidik anak agar bisa hidup mandiri. Materi selanjutnya yang dibutuhkan orang tua adalah tentang tumbuh kembang (perkembangan) anak. Dengan mengetahui tumbuh kembang anak, orang tua juga akan memahami perkembangan fisik dan psikologis anak yang menjadi acuan untuk memantau kesehatan anak, pola asuh sehat serta melatih toilet training secara tepat.

Bagian penting ketiga dari penelitian pengembangan model terpadu pendidikan karakter untuk anak sejak dini yang berkait dengan pola asuh anak adalah seberapa banyak intensitas para ibu dalam satuan waktu bulan dan minggu mengikuti kegiatan "Sekolah Ibu" yang akan dilaksanakan pada saat dari uji coba pengembangan model pendidikan karakter untuk anak-anak sejak dini yang informasinya disajikan pada Gambar 5.

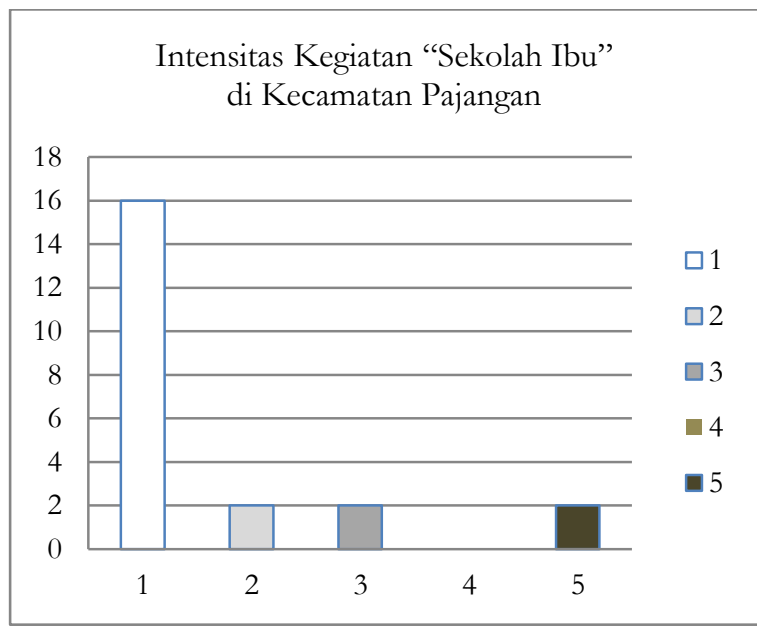

Gambar 5. Intensitas Kegiatan

"Sekolah Ibu" di Kecamatan Pajangan

Data hasil penelitian lapangan seperti ditunjukkan grafik tersebut, menginformasikan bahwa pelaksanaan "Sekolah Ibu" di

Model Pendidikan Karakter bagi Anak Sejak Dini ... - 237

Yoyon Suryono, Puji Yanti Fauziah 
Kecamatan Pajangan lebih banyak dikehendaki dilaksanakan tiap satu bulan sekali (pilihan 1) oleh sekitar 76\% responden yang menjadi sampel penelitian ini. Data selanjutnya dapat diketahui bahwa 10\% responden menghendaki pelaksanaan kegiatan "Sekolah Ibu" diselenggarakan tiap 2 minggu (pilihan 2), 1 minggu (pilihan 3) dan 3 bulan sekali (pilihan 5). Hasil penelitian menunjukkan bahwa tidak ada satu pun responden yang menghendaki pelaksanaan "Sekolah Ibu" tiap 2 bulan sekali (pilihan 4). Atas dasar data itu dapat diambil kesimpulan bahwa pelaksanaan "Sekolah Ibu" dapat dilakukan setiap 1 bulan sekali sesuai dengan permintaan sebagian besar orang tua di Kecamatan Pajangan Kabupaten Bantul.

Kapan "Sekolah Ibu" itu dilaksanakan? Pilihan jawaban yang disediakan adalah pilihan 1 pagi hari, pilihan 2 sore hari, dan pilihan 3 malam hari. Pilihan responden menunjukkan bahwa sore hari merupakan pilihan waktu yang banyak disepakati dibanding dilaksanakan pada waktu pagi dan malam hari. Hal ini dapat dimaklumi karena kalau pagi hari merupakan waktu untuk bekerja di rumah dan di luar rumah, malam hari untuk beristirahat, dan sore hari merupakan waktu senggang dan waktu untuk melaksanakan kegiatan-kegiatan kemasyarakatan.

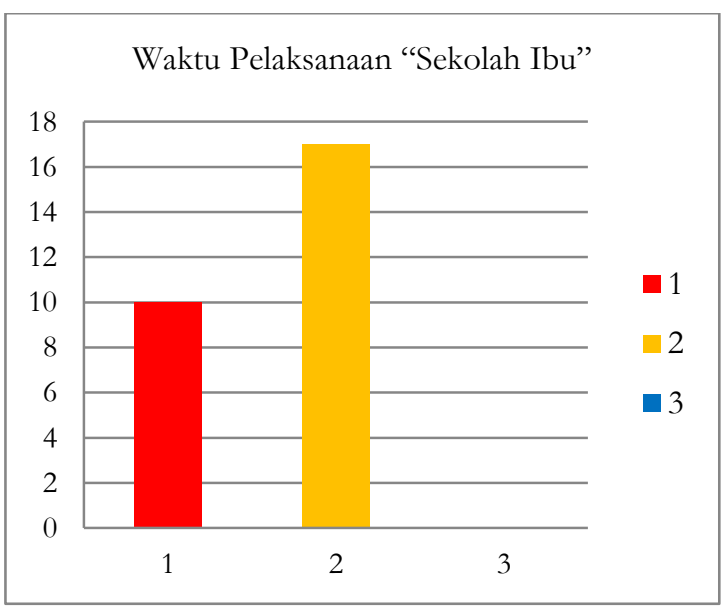

Gambar 6. Waktu Pelaksanaan "Sekolah Ibu"

Bagian terakhir dari hasil penelitian yang berkait dengan pola pengasuhan anak dan pengembangan model pendidikan ka- rakter sejak dini melalui model "Sekolah Ibu" adalah harapan orang tua terhadap pelaksanaan "Sekolah Ibu" yang akan dikembangkan modelnya melalui penelitian ini dan hasil kajian lapangannya telah disampaikan dalam uraian tersebut.

Berdasarkan hasil penelitian lapangan dapat diketahui bahwa harapan orang tua terhadap "Sekolah Ibu" antara lain: yang paling banyak adalah mengharap mempunyai keterampilan dan metode pendidikan. Selanjutnya, orang tua mengharap anak bisa mandiri, mendapatkan pendidikan yang benar dan baik untuk anak baik di rumah maupun di sekolah. Harapan selanjutnya agar dapat menambah wawasan, tambah pengalaman, tambah ilmu, mengetahui tumbuh kembang anak, memotivasi anak lebih rajin belajar serta mengembangkan pendidikan anak yang tepat dan dapat dipraktikkan dalam kehidupan sehari-hari.

\section{Pembahasan}

Data yang disajikan tersebut tentang lembaga PAUD nonformal di pedesaan yang telah melaksanakan pendidikan karakter sejak dini dalam wadah KB dan SPS dan telah melaksanakan standar PAUD yang telah ditetapkan memberi informasi beberapa hal penting yang dapat diringkas sebagai berikut. Pertama, terdapat dua kelompok besar satuan pendidikan nonformal di pedesaan yang sedang melaksanakan layanan pendidikan anak usia dini yaitu $\mathrm{Ke}$ lompok Bermain (KB) dan satuan pendidikan sejenis (SPS). Dalam dua kelompok besar ini terselip juga kegiatan layanan PAUD dalam bentuk Taman Penitipan Anak (TPA) yang sering ditemui menyatu baik dengan KB maupun SPS. Kedua, dilihat dari sejauh mana KB dan SPS ini melaksanakan 4 (empat) standar PAUD yang telah ditetapkan (di dalamnya sebenarnya berisi 8 (delapan) standar PAUD), data yang diperoleh menunjukkan pengkategorian secara bertingkat yaitu KB dan SPS berada di peringkat tinggi, $\mathrm{KB}$ dan SPS berada di peringkat sedang, dan terdapat juga KB dan SPS berada pada peringkat rendah atas dasar pensekoran yang digunakan dalam penelitian ini. Ketiga, profil KB dan SPS 
yang telah melaksanakan standar PAUD secara substansi menunjukkan kecenderungan bahwa pada umumnya tingkat pencapaian perkembangan anak jauh lebih tinggi perolehan sekornya dibanding dengan tingkat pencapaian pelaksanaan standar PAUD pada aspek-aspek standar lainnya seperti pada standar pendidik dan tenaga kependidikan, standar isi, proses, dan penilaian, serta pada standar sarana dan prasarana, pengelolaan, dan pembiayaan. Aspek yang terakhir ini berkecenderungan berada pada posisi bawah. Keempat, dalam rumusan yang singkat, kecenderungan tingkat pencapaian pelaksanaan standar PAUD menunjukkan bahwa aspek keluaran lebih tinggi dibanding dengan aspek proses dan masukannya. Apakah hal ini menunjukkan fenomena yang menarik dari sudut pembelajaran bahwa di PAUD terjadi proses pembelajaran yang mementingkan keluaran dibanding prosesnya? Jawabannya masih memerlukan kajian lebih mendalam. Kelima, posisi KB dan SPS sebagai institusi layanan PAUD nonformal di pedesaan tidak menunjukkan adanya signifikansi, artinya baik KB maupun SPS memiliki peran yang sama dan seimbang dalam melaksanakan layanan PAUD nonformal di pedesaan.

Hal ini berarti pada keduanya memiliki sumbangan dan dukungan yang besar dalam melaksanakan pendidikan anak usia dini melalui jalur pendidikan nonformal, selaras dengan layanan pendidikan anak usia dini melalui jalur formal dalam wadah Taman kanak-kanak (TK). Keenam, meskipun atas dasar data yang diperoleh menunjukkan adanya pengkategorian KB dan SPS dalam melaksanakan standar PAUD, namun pada dasarnya hal itu lebih berkait dengan tingkat perkembangan masing-masing lembaga seperti berapa lama didirikan, siapa penyelenggara dan pengelolanya, dan tentu berkait juga dengan aspek-aspek kesejarahan lainnya.

Data tentang pola pengasuhan anak oleh orang tua menunjukkan masih dominannya pola asuh orotiter, yaitu pola asuh yang memperlihatkan "kekuasaan" orang tua terhadap anak-anaknya. Hal ini dapat dimengerti karena persepsi dan pendapat yang masih berkembang di lingkungan masyarakat adalah peran orang tua terhadap anak masih sangat kuat yang tidak jarang menjadi berlebihan sehingga anak kurang berkembang kemandiriannya.

Ditemukan juga ada pola asuh yang demokratis, tetapi posisinya berada di bawah pola asuh otoriter. Hal ini menunjukkan bahwa pada masyarakat telah berkembang bentuk pola asuh lain seperti yang selama ini berkembang yaitu pola asuh otoriter. Pola asuh demokratis menempatkan posisi anak pada posisi "memiliki" banyak kemungkinan untuk berkembang kemandiriannya serta mengembangkan potensipotensi lain yang dalam perkembangannya didorong kuat oleh orang tuanya.

Data tentang perilaku orang tua yang sering dan jarang dilakukan menunjukkan keadaan sebagai berikut. Pertama, hal-hal yang sering dilakukan oleh orang tua adalah mendampingi kegiatan anak, meminta anak membereskan mainan, mengajarkan kata maaf, membiarkan anak bereksplorasi, mengajarkan kata permisi, memberikan saran, membantu mempersiapkan keperluan anak, dan menyuapi anak ketika makan. Pilihan atas jenis perilaku orang tua seperti ini kurang begitu banyak, padahal jenis pilihan perilaku ini mencerminkan pola asuh demokratis di dalam keluarga. Kedua, halhal yang kadang-kadang dilakukan oleh orang tua terhadap anak adalah menerapkan aturan dengan konsisten, mendukung minat/hobi anak yang berbeda dengan anak lain, marah jika anak "ngeyel", dan mengontrol semua aktivitas anak. Jenis pilihan perilaku orang tua seperti ini menunjukkan pola pengasuhan anak yang berada di posisi tengah, antara otoriter dan demokratis. Apakah pola pengasuhan jenis ini lebih bernuansa permisif? Ketiga, hal-hal yang jarang dilakukan oleh orang tua terhadap anak adalah mendongeng untuk anak, memukul/mencubit/memberi hukuman agar disiplin, merasa keberatan jika anak protes, membuat program kegiatan dengan rinci untuk anak, membiarkan anak menyelesaikan masalahnya sendiri, mendidik anak de- 
ngan keras untuk kebaikan dirinya sendiri, dan memberikan apapun yang anak minta. Menentukan batas-batas pasti antara pola asuh otoriter, demokratis, dan permisif kadang tidak begitu mudah karena dalam praktik pengasuhan anak cenderung pola asuh itu dapat berganti-ganti tergantung pada konteks dan kebutuhannya.

Data lain yang ditemukan adalah sesuatu yang berkait dengan bagaimana merancang dan melaksanakan pendidikan karakter sejak dini melalui "Sekolah Ibu" nonformal di pedesaan. Beberapa masukan yang diperoleh di lapangan tentang "Sekolah Ibu" sebagai berikut. Pertama, materi yang penting untuk "Sekolah Ibu" adalah: (a) tumbuh kembang anak, (b) metode pendidikan anak, (c) kesehatan anak, (d) pola asuh sehat di rumah, (e) mendidik kemandirian anak, (f) latihan ke "toilet", dan (g) pilihan lain sesuai pendapat orang tua. Kedua, masukan yang diperoleh untuk melaksanakan "Sekolah Ibu" lebih banyak menunjuk pada dilaksanakan setiap bulan dan waktunya pada sore hari. Masukan ini masuk akal karena sesuai dengan kondisi orang tua, lingkungan, dan aktivitas harian lain yang dilakukan oleh orang tua.

Adapun model rancangan konseptual yang dibuat berdasarkan hasil identifikasi kebutuhan di lapangan dapat dilihat dalam Gambar 1.

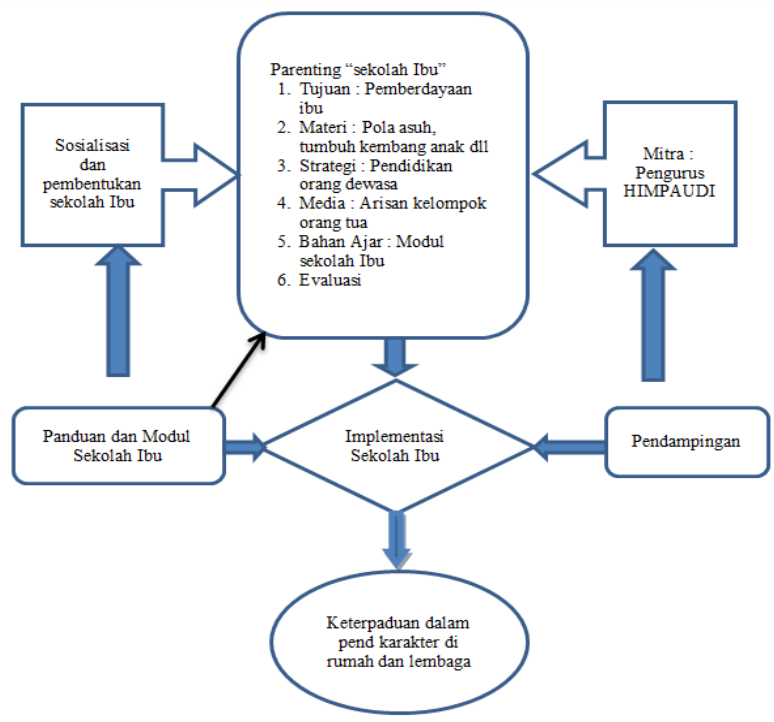

Gambar 7. Model Konseptual Sekolah Ibu
Sebagai kesimpulan, beberapa hal berikut ini harus menjadi bahan atau materi penting dalam merancang dan melaksanakan pendidikan karakter sejak dini melalui "Sekolah Ibu" nonformal di pedesaan: (1) Model "Sekolah Ibu" merupakan perluasan pengembangan program yang sifatnya tentatif dari satuan pendidikan anak usia dini yang sudah ada yaitu Kelompok Bermain (KB) dan Satuan Pendidikan Sejenis (SPS) yang ada di lokasi penelitian ini yaitu di Kecamatan Pajangan, Kabupaten Bantul, Provinsi DIY; (2) setiap KB dan SPS ditetapkan 2 (dua) lembaga yang berasal dari kelompok tinggi dan rendah secara acak. Jumlah lembaga KB dan SPS yang akan terlibat dalam "Sekolah Ibu" sebanyak 4 lembaga; (3) pilihan peserta (orang tua) yang akan mengikuti kegiatan ini berasal dari lembaga tersebut dengan memperhatikan kebiasaan pola asuh dan latar belakang lain seperti lokasi, ekonomi keluarga, dan pendidikan formal yang telah diselesaikan, sehingga peserta ini diharapkan memiliki latar belakang yang beragam; (4) oleh karena peserta pada umumnya adalah orang dewasa maka proses pembelajarannya harus dirancang untuk keperluan orang dewasa. Akan tetapi, karena orang tua juga harus melaksanakan pendidikan karakter sejak dini kepada anak-anaknya maka materi pembelajaran bagi anak akan diberikan juga kepada para orang tua, termasuk materi tentang pola pengasuhan anak; (5) materi yang perlu diberikan kepada orang tua dan anak adalah materi tentang pendidikan karakter sejak dini, dan disajikan dalam bentuk modul pembelajaran yang dirancang untuk orang tua dan anak dengan cara atau metoda yang berbeda; (6) muatan materi untuk pola pengasuhan anak merujuk pada pilihan materi yang dipilih oleh orang tua seperti disajikan dalam hasil penelitian tersebut sehingga materi pembelajaran pendidikan karakter bagi anak sejak dini merujuk pada pilihan materi yang sudah dipilih oleh orang tua; (7) "Sekolah Ibu" dilaksanakan sebulan sekali selama enam bulan dan setiap kali pertemuan berlangsung selama 2 sampai 3 jam secara variatif dilaksanakan pada waktu sore 
hari yang dirancang bersama-sama dengan kegiatan bagi anak dalam format $\mathrm{KB}$ dan SPS; (8) Lokasi dan tempat "Sekolah Ibu" bergantian di tempat KB dan SPS berada yang ditetapkan sebagai satuan PNF yang mengikuti kegiatan uji coba penelitian ini; (9) Kegiatan pengembangan model pendidikan karakter bagi anak sejak dini melalui "Sekolah Ibu" nonformal di pedesaan ini memerlukan kerja sama kemitraan di tingkat kecamatan dan kalurahan baik dengan pemerintah setempat, penyelenggara dan pengelola KB dan SPS maupum HIMPAUDI setempat; (10) format bahan ajar dalam bentuk modul yang berisi tentang pendidikan karakter bagi anak disesuaikan dengan teori pembelajaran dan karateristik anak usia dini pada umumnya, dam pertimbangan lokasi penyelenggaraan kegiatan di pedesaan; (11) kegiatan uji coba pengembangan model ini dibantu oleh penyelenggara dan pengelola $\mathrm{KB}$ dan SPS serta tenaga pendidik dan kependidikan setempat yang sebelumnya memperoleh pembekalan dan pengayaan materi tentang pola pengasuhan, pembelajaran anak usia dini, dan materi tentang pendidikan karakter bagi anak; (12) sesuai dengan persyaratan metodologi maka sebelum uji coba dilaksanakan didahului kegiatan validasi model konseptual-teoritik oleh para ahli pembelajaran dan pendidikan anak ujia dini, termasuh juga ahli pengembangan media pembelajaran dalam konteks pendidikan nonformal dan informal.

\section{Simpulan dan Saran}

Simpulan

Pencapaian tingkat perkembangan anak (sebagai keluaran hasil belajar) pada umumnya lebih baik dibanding dengan tingkat pencapaian standar pendidik dan tenaga kependidikan, standar isi, proses, dan penilaian, serta standar sarana prasarana, pengelolaan, dan pembiayaan.

Temuan itu menunjukkan juga bahwa pendidikan karakter bagi anak sejak dini sudah dilaksanakan secara khusus oleh institusi PAUD nonformal yang dikenal dengan nama KB dan SPS. Akan tetapi, masih kurang menunjukkan keterpaduan dengan pola pengasuhan anak yang dilakukan oleh orang tua di rumah karena masih ditemukan adanya perilaku orang tua masih yang beragam, ada perilaku yang sering dilakukan, kadang-kadang dilakukan, dan juga ada yang sama sekali tidak dilakukan.

Model "Sekolah Ibu" merupakan perluasan pengembangan program yang sifatnya tentatif dari Kelompok Bermain (KB) dan Satuan Pendidikan Sejenis (SPS) yang ada di Kecamatan Pajangan, Kabupaten Bantul, Provinsi DIY. Setiap KB dan SPS ditetapkan 2 (dua) lembaga yang berasal dari kelompok tinggi dan rendah secara acak. Jumlah lembaga KB dan SPS yang akan terlibat dalam "Sekolah Ibu" se-banyak 4 lembaga.

\section{Saran}

Untuk lebih meningkatkan lagi pencapaian perkembangan anak sebagai hasil belajar, perlu meningkatkan ketercapaian standar-standar yang lain yaitu standar pendidik dan tenaga kependidikan, standar isi, proses, dan penilaian, standar sarana dan prasarana, pengelolaan, dan pembiayaan secara bertahap sesuai kemampuan masingmasing lembaga (SPS dan KB di masingmasing lokasi.

Untuk mengembangkan model konseptual-teoretik "Sekolah Ibu" perlu memperhatikan beberapa hal berikut yaitu (a) prioritas sasaran peserta dari SPS atau KB yang terpilih menjadi lokasi uji coba, (b) tujuan yang perlu dicapai ditekankan pada pemahaman para orang tua terhadap pola pengasuhan anak yang mendukung pendidikan karakter di dalam keluarga, (c) proses pembelajaran untuk orang tua dilaksanakan atas dasar pendekatan andragogik dan pembelajaran berbasis pada pemecahan masalah dan belajar sambil melakukan, (d) menggunakan media pembelajaran yang mudah didapat di lokasi uji coba atas dasar pemanfaatan sumber-sumber yang mudah di dapat, (e) materi pembelajaran ditekankan pada pola asuh dan pendidikan karakter untuk anak sejak dini, (f) pelaksanaan teknis pembelajaran hendaknya dibicarakan bersama 
antara peneliti, tenaga pendidik, dan peserta didik yang akan terlibat dalam uji coba ini, dan (g) sebelum uji coba secara metodologi perlu validasi rancangan ini oleh para ahli.

\section{Daftar Pustaka}

Berk, L. E (2003). Child development, sixth edition. USA. Illinois State University.

Biech, E. (1996) Creativity and innovation the ASTD trainers source book. New York: McGraw Hills Companies.

Bodrova, E \& Leong J.D (1996) Tools and of the mind: A case study of implementing the Vyotskian approach in American early childhood and primary classroom. Berau: UNESCO. Online di http://www. ibe.unesco.org/publications/innodata $\angle$ inno07.pdf (dikases tanggal 8 Maret 2010).

Borg \& Gall, M.D. (1979). Educational research an introduction. New York: Longman Inc.

Bower, H.G \& Earnest R.H (1981). Theories of learning. New Jersey: Prentice hall, Inc. Eanglewood Cliff.

Coles Robert (2003) Menumbubkan kecerdasan moral pada anak. Jakarta. Gramedia.

Dahlan, M.D 92006) Pendidikan anak usia dini dalam perspektif Al-qur'an. Bandung: Halima.

Dewantaras, S. (1989) 100 tabun Ki Hajar Dewantara Bapak Pendidikan. Jakarta: Pustaka Kartini.

Djalal, F (2004) Arah kebijakan nasional pendidikan anak usia dini (jalur pendidikan non formal) Disampaikan pada acara seminar dan Lokakarya $\mathrm{Na}$ sional Universitas Negeri Jakarta.

Dryden , G \& Vios, J (2002) Revolusi cara belajar. Bandung: Kaifa.

Harahap, H.A.H. \& Dewantara, S. B. (1980) Ki Hajar Dewantara ditangkap dipenjara- kan dan diasingkan. Jakarta: Gunung Agung.

Harkonen. U (tanpa tahun). Defining early childhood Education and through system theory. Finland: University of Joensuu. http://sokl.joensuu.fi/harkonen/verk ot/defining $\% 20$ early-Article.pdf (diakses Maret 2010).

Harris, et all. (1995) Competency based education an training: Between a rock and whirlpool. Australia: MacMillan Education Australia.Ltd.

Hurlock, E (1999) Perkembangan anak jilid 2. Jakarta: Erlangga.

Izzati, R. E. (2005) Peranan aktivitas pengasuban pada pembentukan perilaku anak sejak usia dini. Yogyakarta: Tiara Kencana.

Lickona. T (1992). Educating for character. how our schools can teach respect and responbillity. New York: Bantam Books.

Sudjana, D. (2005) Manajemen program pendidikan luar sekolah. Bandung. AlFalah

Sumarno. (2010) Pengembangan model life skills (DLS) untuk pengentasan kemiskinan. Makalah: Jurusan PLS FIP UNY.

Suryono, Y. (2010) Pendidikan nonformal dan pengurangan kemiskinan di pedesaan (pengembangan model program pendidikan kecakapan hidup) di Propinsi DIY. Lembaga Penelitian UNY (tidak dipublikasikan).

Tilman Diane (2004). Living values activities children ages 8-14. Jakarta: Grasindo.

Ulwan, A.N 91999). Pendidikan anak dalam islam. jilid 2. Jakarta: Pustaka Amani

Verenikina Irina. Understanding Scaffolding and the ZPD in Educational Research.

Http://education.stateuniversity.com. 